\title{
Polycystic ovary syndrome: controversies and challenges
}

\section{SíNDROME dO OVÁRIO POLICÍSTICO: CONTROVÉRSIAS E DESAFIOS}

\author{
José Maria Soares Júnior ${ }^{1}$, Maria Cândida P. Baracat² ${ }^{2}$ Gustavo Arantes Rosa Maciel ${ }^{3}$, Edmund Chada Baracat ${ }^{4}$ \\ ${ }^{1}$ Associate Professor, Division of Gynecology, Department of Obstetrics and Gynecology, Faculdade de Medicina, Universidade de São Paulo (FMUSP), São Paulo, SP, Brazil \\ ${ }^{2}$ Assistant, Division of Gynecology, Department of Obstetrics and Gynecology, FMUSP, São Paulo, SP, Brazil \\ ${ }^{3}$ Assistant, Habilitation (BR: Livre Docência, Division of Gynecology, Department of Obstetrics and Gynecology, FMUSP, São Paulo, SP, Brazil \\ ${ }^{4}$ Full Professor, Division of Gynecology, Department of Obstetrics and Gynecology, FMUSP, São Paulo, SP, Brazil \\ http://dx.doi.org/10.1590/1806-9282.61.06.485
}

One of the biggest challenges in medicine is that of polycystic ovary syndrome (PCOS) because of its complexity, its progression aspect and the consequences it entails for women's lives: from adolescence to post-menopause. It affects a large number of women, ranging from $6 \%$ to $8 \%$ of the population during the reproductive years. So this condition is very important. ${ }^{1-6}$

It is known that PCOS is not characterized by the association of hyperandrogenism and chronic anovulation only, but also involves disorders of carbohydrate metabolism, with a focus on insulin resistance and increased risk of developing diabetes. The latter is higher with increases in weight and ultimately the appearance of obesity, leading to dyslipidemia, metabolic syndrome and increased possibility of malignancies such as endometrial carcinoma. ${ }^{1-6}$

Although the description of the clinical picture had been reported in the literature before the twentieth century, this syndrome was recognized by the work of two American surgeons, Stein e Leventhal, in 1935. ${ }^{1}$ Since then, several publications have been made looking for a single agent to justify PCOS. ${ }^{2-5}$ However, the interaction between genetic, environmental, behavioral and psychological factors is, to date, the best way to understand this condition and its various phenotypes.

Some researchers believe that PCOS is the result of a disorder that begins during pregnancy, generating a low birth weight (less than $2,500 \mathrm{~g}$ or less than $10 \%$ of expected weight for gestational age) or macrosomic (weighing over 3,800g) newborn. In both cases, there would be more risk of developing the disease involving insulin metabolism. Depending on the habits (sedentary lifestyle and poor diet), there could be worsened hyperinsulinemia and early pubarche, a clinical sign suggestive of greater chances of developing PCOS. ${ }^{1-7}$

Other important factors are heredity (mothers with PCOS) and genetics. There are several genes that can serve as biomarkers, including GTF2A1L and LHCGR (plays a crucial role in luteinizing hormone $[\mathrm{LH}]$ receptors). ${ }^{8}$ Other researchers believe that two polymorphisms of the THADA (thyroid adenoma associated) gene, follicle-stimulating hormone (FSH) receptor and DENND1A gene ${ }^{9}$ would often be found in PCOS women. However, many agree that environmental, behavioral and psychological factors associated with genes would be essential for the emergence of PCOS. It is also known that changes in life habits per se could alleviate the symptoms associated with PCOS, particularly improving the ovulation pattern and fertility in these women. ${ }^{10}$

Insulin metabolism is also associated with higher risks of developing cardiovascular disease and cancer, as well as infertility. The main change would be a post-receptor defect involving reduced substrate for tyrosine and increased phosphorylation of serine residues in the intracellular signal from the insulin receptor. The end result would be the collapse of GLUT-4 protein on the cell surface and difficulty in glucose metabolism with subsequent hyperinsulinism as a pancreatic response. This clinical condition can also progress to glucose intolerance, which would facilitate the emergence of diabetes mellitus ${ }^{11}$ and increase the risk of cardiovascular disease.

Excessive insulin has a direct effect on the ovary, extending the action of $\mathrm{LH}$ on androgen production, and also determines further degradation of the proteins carrying androgenic steroids and growth factors. There would thus be the amplification of the effects of androgens and of substances that can increase cell proliferation, increasing the risk of cancer. ${ }^{12,13}$

Although PCOS has hyperandrogenism as a central feature, its diagnosis is also based on the exclusion of other conditions that may present similar clinical picture. Thus, the diagnosis is based on expert consensuses. These include panels promoted by the US National Institute of Health (NIH) in $1990^{14}$ and the Rotterdam consensus, organized by the American Society for Reproductive Medicine (ASRM) and the European Society of Human Reproduction and Embryology (ESHRE), in 2003. ${ }^{15}$ The latest and most accepted consensus is that issued by the Androgen Excess and Polycystic Ovary Syndrome (AES-PCOS) Society, which recommends that women neces- 
sarily have clinical or laboratory hyperandrogenism associated with chronic anovulation and/or polycystic ovaries images. ${ }^{16}$ Carbohydrate or lipid metabolism disorders are not part of the diagnosis, but are important factors for prognosis, mainly due to cardiovascular risk.

In general, the therapy employed does not address the cause, but ameliorates the effects or complications associated with the disease: a) menstrual dysfunction; $b$ ) hyperandrogenism; c) infertility; d) metabolic changes; e) prevention of cardiovascular diseases and cancer.

The main pillar of therapy is to change lifestyle habits, increasing physical activity (3 to $5 x$ per week), reducing daily stress, proper nutritional diet and psychological support. ${ }^{10,17}$ If there is no adherence to treatment or if the response is inadequate, drug therapy is recommended. Exceptionally, laparoscopic ovarian drilling is an alternative used in extreme cases, in which there was no successful medical treatment. ${ }^{18}$

In overweight and obese women, the main strategy is weight loss. With reduction greater than $5 \%$, there may be clinical improvement with recovery of menstrual pattern and ovulation. Curi et al. ${ }^{10}$ showed that physical activity 40 minutes a day, three times a week, associated with appropriate nutritional diet has an effect similar to metformin. In addition, changes in life habits provide another beneficial effect: reduction of the abdominal circumference (related to the visceral fat and cardiovascular risk).

Regarding menstrual patterns and hirsutism, combined oral hormonal contraceptives are very effective because they reduce the circulating levels of androgens, regulate the cycles, and protect the endometrium. ${ }^{19}$ However, this treatment does not improve insulin resistance, and may eventually even worsen it depending on the type of progestogen used.

In more severe cases of hirsutism, anti-androgenic agents, such as cyproterone acetate, spironolactone, finasteride and flutamide, may be added. The latter drug should be used with caution due to deleterious effects to the liver. ${ }^{20}$ Usually, creams with these active ingredients and other cosmetic procedures can be adjuvants for faster skin improvement.

For carbohydrate metabolism, the primary product remains metformin, ${ }^{21}$ but the development of biological drugs which help weight loss, such as liraglutide, may be promising. ${ }^{22}$

Although stimulation of ovulation is effective with the use of clomiphene, pregnancy rates are not high, requiring more complex techniques of assisted reproduction. Perhaps the genetic and morphological changes of the endometrium are crucial in the fertility of women with PCOS. ${ }^{13}$

More than a reproductive disorder, PCOS should be viewed as a complex metabolic disease that requires global therapeutic approach, since it is a risk factor for diseases such as diabetes and endometrial cancer and possibly cardiovascular disease.

Treatment should be individualized according to clinical presentation, whether the patient wants to become pregnant, and the risk of developing long-term complications.

\section{References}

1. Stein IF, Leventhal ML. Amenorrhea associated with bilateral polycystic ovaries. Am J Obstet Gynecol. 1935; 29(2):181-91.

2. Rosenfield RL. The diagnosis of polycystic ovary syndrome in adolescents. Pediatrics. 2015; 136(6):1154-65.

3. Lenart-Lipińska M, Matyjaszek-Matuszek B, Woźniakowska E, Solski J, Tarach JS, Paszkowski T. Polycystic ovary syndrome: clinical implication in perimenopause. Prz Menopauzalny. 2014; 13(6):348-51.

4. Morris S, Grover S, Sabin MA. What does a diagnostic label of "polycystic ovary syndrome" really mean in adolescence? A review of current practice recommendations. Clin Obes. 2015 (ahead of print).

5. Lanzo E, Monge M, Trent M. Diagnosis and management of polycystic ovary syndrome in adolescent girls. Pediatr Ann. 2015; 44(9):e223-30.

6. Azziz R, Woods KS, Reyna R, Key TJ, Knochenhauer ES, Yildiz BO. The prevalence and features of the polycystic ovary syndrome in an unselected population. J Clin Endocrinol Metab. 2004; 89(6):2745-9.

7. Melo AS, Bettiol H, Silva AA, Rosa-e-Silva AC, Cardoso VC, Reis RM et al. Small for gestational age babies are not related to changes in markers of adipose tissue dysfunction during reproductive age. Early Hum Dev. 2014; 90(5):231-5.

8. Thathapudi S, Kodati V, Erukkambattu J, Addepally U, Qurratulain H. Association of luteinizing hormone chorionic gonadotropin receptor gene polymorphism (rs2293275) with polycystic ovarian syndrome. Genet Test Mol Biomarkers. 2015; 19(3):128-32.

9. Brower MA, Jones MR, Rotter JI, Krauss RM, Legro RS, Azziz R, Goodarzi MO. Further investigation in europeans of susceptibility variants for polycystic ovary syndrome discovered in genome-wide association studies of Chinese individuals. J Clin Endocrinol Metab. 2015; 100(1):E182-6.

10. Curi DD, Fonseca AM, Marcondes JA, Almeida JA, Bagnoli VR, Soares JM Jr et al. Metformin versus lifestyle changes in treating women with polycystic ovary syndrome. Gynecol Endocrinol. 2012; 28(3):182-5.

11. Legro RS. Type 2 diabetes and polycystic ovary syndrome. Fertil Steril. 2006; 86(Suppl 1):S16-7.

12. Pillay OC, Te Fong LF, Crow JC, Benjamin E, Mould T, Atiomo W et al. The association between polycystic ovaries and endometrial cancer. Hum Reprod. 2006; 21(4):924-9.

13. Baracat MC, Serafini PC, Simões R dos S, Maciel GA, Soares JM Jr, Baracat EC. Systematic review of cell adhesion molecules and estrogen receptor expression in the endometrium of patients with polycystic ovary syndrome. Int J Gynaecol Obstet. 2015; 129(1):1-4.

14. Hsu MI, Liou TH, Chou SY, Chang CY, Hsu CS. Diagnostic criteria for polycystic ovary syndrome in Taiwanese Chinese women: comparison between Rotterdam 2003 and NIH 1990. Fertil Steril. 2007; 88(3):727-9.

15. ESHRE/ASRM. Revised 2003 consensus on diagnostic criteria and long-term health risks related to polycystic ovary syndrome (PCOS). Hum Reprod. 2004; 19(1):41-7.

16. Legro RS, Arslanian SA, Ehrmann DA, Hoeger KM, Murad MH, Pasquali R et al. Diagnosis and treatment of polycystic ovary syndrome: an endocrine society clinical practice guideline. J Clin Endocrinol Metab. 2013; 98(12):4565-92.

17. Goodman NF, Cobin RH, Futterweit W, Glueck JS, Legro RS, Carmina E. American Association of Clinical Endocrinologists, American College of Endocrinology, and Androgen Excess and PCOS Society Disease State Clinical Review: guide to the best practices in the evaluation and treatment of polycystic ovary syndrome - Part 2. Endocr Pract. 2015; 21(12):1415-26. 
18. Liu W, Dong S, Li Y, Shi L, Zhou W, Liu Y et al. Randomized controlled trial comparing letrozole with laparoscopic ovarian drilling in women with clomiphene citrate-resistant polycystic ovary syndrome. Exp Ther Med. 2015; 10(4):1297-1302.

19. Iwata MC, Porquere L, Sorpreso IC, Baracat EC, Soares JM Jr. Association of oral contraceptive and metformin did not improve insulin resistance in women with polycystic ovary syndrome. Rev Assoc Med Bras. 2015; 61(3):215-9.

20. Nakano K, Ando H, Kurokawa S, Hosohata K, Ushijima K, Takada M et al. Association of decreased mRNA expression of multidrug and toxin extrusion protein 1 in peripheral blood cells with the development of flutamide-induced liver injury. Cancer Chemother Pharmacol. 2015; 75(6):1191-7.

21. Maciel GA, Soares JM Jr, Alves da Motta EL, Abi Haidar M, de Lima GR, Baracat EC. Nonobese women with polycystic ovary syndrome respond better than obese women to treatment with metformin. Fertil Steril. 2004; 81(2):355-60.

22. Jensterle M, Pirš B, Goričar K, Dolžan V, Janež A. Genetic variability in GLP1 receptor is associated with inter-individual differences in weight lowering potential of liraglutide in obese women with PCOS: a pilot study. Eur J Clin Pharmacol. 2015; 71(7):817-24 